\title{
ÇÜRÜK AKTİVİTE TESTLERİ (DERLEME)
}

\section{CARIES ACTIVITY TESTS (REVIEW)}

\section{Dok. Öğr. Dt. Ayberk İMREN* \\ Prof Dr. Elif Bahar TUNA İNCE*}

\author{
Arş. Gör. Dr. Mine KORUYUCU* \\ Prof.Dr. Mehmet Tevfik AKINCI*
}

Makale Kodu/Article code: 3826

Makale Gönderilme tarihi: 01.10 .2018

Kabul Tarihi; 08.01.2019

DOI : $10.17567 /$ ataunidfd.596806

\author{
Ayberk İmren: ORCID ID: 0000-0002-8992-7990 \\ Mine Koruyucu: ORCID ID: 0000-0002-2077-5095 \\ Elif Bahar Tuna İnce: ORCID ID: 0000-0001-6450-6869 \\ Mehmet Tevfik Akıncı: ORCID ID: 0000-0003-4027-2257
}

\section{öz}

Diş çürüğü; mikroorganizma ve besinin diş yüzeyinde aynı zaman diliminde bulunması ile bakterinin diş ile ilișkisinin bozulması sonucunda oluşmaktadır. Çürük lezyonları klinik muayene ile incelenmekte ve tedavi edilmektedir. Ancak klinik muayene çürük aktivitesini önceden tahmin edememektedir. Bu alanda yapılan çalışmalar, günümüzde yoğun şekilde ilerlemektedir. Bu çalışmalardaki ana hedef, kişilerin bireysel çürük aktivitesini ölçmek ve bunun sonucuna göre koruyucu önlemler almaktır. Bu derlemede, günümüzde mevcut olan çürük aktivite testleri ve cariogram programı hakkında bilgiler bulunmaktadır.

Anahtar Kelimeler: diş hekimliği, çürük aktivite testleri, çürük risk faktörleri

\section{ABSTRACT}

Tooth caries occurs when microorganism and nutrients are found in the same time zone on the tooth surface, it is caused by the deterioration of the relation of the bacteria with the tooth. Caries lesions are examined through clinical diagnoses and treated. However, clinical diagnoses cannot predict caries in advance. Studies in this area are continuing today. The goal of these studies is to determine the predilection of people to caries and take the appropriate protective precautions. In this review, there is information about caries activity tests and cariogram program.

Key Words: dentistry, caries activity test, risk factors of caries

\footnotetext{
* İstanbul Üniversitesi Diș Hekimliği Fakültesi Pedodonti AD, İstanbul
}

Kaynakça Bilgisi: İmren A, Koruyucu M, Tuna İnce EB, Akıncı MT. Çürük Aktivite Testleri (Derleme). Atatürk Üniv Diş Hek Fak Derg 2020; 30: 330-336 Citation Information: Imren A, Koruyucu M, Tuna Ince EB, Akinci MT. Caries Activity Tests (Review).J Dent Fac Atatürk Uni 2020; 30 : 330-336

\section{GİRIş}

Diş çürüğü içsel ve dışsal nedenlere dayalı olarak ağız içinde bulunan organizmalar ve besin birikintilerinin dişlerle etkileşimi sonucu ortaya çıkan olaylar zinciri olarak tanımlanır. Çürük gözle görülebilir hale gelmeden çok uzun zaman önce oluşmaya başlamaktadır. Diş çürüğü açısından yüksek risk grubunda bulunan bireylerin önceden belirlenmesi ve koruyucu tedavilerin yapılması önem taşımaktadır. ${ }^{1-3}$

Güncel diş hekimliğinde, diş çürüğünün tedavi edilmesindense dişin hastalıktan korunmasının öncelikli hale geldiği bilinmektedir. Birçok hastalıkta olduğu gibi, diş çürüğünde de erken teşhis uygulanacak koruyucu yöntemlerin etkisini o denli artırır. ${ }^{4}$
Çürük aktivitesinin artmasında Ph değişikliği önemli bir etkendir. Ph değişikliğinde ise en önemli faktörlerden biri diyettir. Çoğu gıdanın karyojenik özeliği olsa da, antikaryojenik özelliklere sahip gıdalar da vardır. Antikaryojenik gıdalarla beslenen insanlarda çürük aktivitesi azalabilir. Literatürde tükürük pH'sı ve diş çürümesi üzerine diyet içeriğinin etkisine yönelik çalışmalar bulunmaktadır. ${ }^{5}$

Diş çürüğü klinik muayenede el aletleri kullanılarak ve çeşitli radyografilerle basit bir şekilde tespit edilebilir. Fakat klinik gözlem ile bireyin çürüğe karşı olan duyarlılığı bilinemez. Koruyucu uygulamaların intiyacının belirlenmesinde, terapötik işlemlerin başarı indeksinin görülmesinde, ağız temizliğindeki işlemlerde, gıda alımının düzenlenmesinde ve hasta motivasyonu sağlanmasında, restoratif işlemlerin başarısının 
takibinde, yüksek risk taşıyan kişi ve/veya grupların tanımlanmasında, hastanın klinik durumunu kolaylaştırmak için laboratuvar testlerine intiyaç duyulmuştur. ${ }^{6}$

Çürük aktivitesi lokal sebeplere bağlı olmasıyla birlikte genetik sebeplere de bağlıdır. Kişiler arasında çürük oluşumuna yatkınlık farklıdır. Diş çürüğü oluşumunda genetik faktörlerin önemi yıllarca araştırılmış ve kabul edilmiştir. Çürük oluşumunda genetik faktörlerin rolü hakkında direkt bir kanıt bulunmasına karşın bu mekanizma hakkında pek fazla şey bilinmemektedir. ${ }^{7}$

Çürük risk incelemesi, diş çürüğünün kontrol altına alınabilmesi için çok önemlidir ve standart muayene olarak görülmelidir. Hekime diagnoz, prognoz ve tedavi önerilerinde karar verirken yol göstermektedir. ${ }^{8}$

\section{Çürük aktivite testlerinin gereksinimleri}

- Testler tekrarlanabilir ve geçerli olmalıdır.

- Çürük aktivite skorları ve gerçek çürük gelişimi arasında iyi bir korelasyon olmalıdır.

- Basit olmalıdır.

- Sonuçlar, saatler veya birkaç gün içinde hızla elde edilmelidir

- Çürük sürecinde yer alan mekanizmaların ölçülmesi gerekmektedir.

- Ucuz olmalı, invaziv olmalıdır. ${ }^{1}$

\section{Tükürük akış hızı}

Tükürük akış hızı tükürüğün içeriğini etkileyen en önemli faktörlerden biridir. ${ }^{9}$ Akış hızının artmasıyla protein, sodyum, bikarbonat ve klorit düzeyi artarken, magnezyum ve fosfat seviyesi azalmaktadır. Hastaların tükürük akış hızının rutin olarak tespiti, hastanın normal akış hızının ve ilerde oluşabilecek değişikliklerin belirlenmesine olanak sağlar. ${ }^{10}$

Tükürük akış hızını etkileyen çevresel ve kişisel bir çok etken bulunmaktadır. Mevsim değişiklikleri, ışık, sigara kullanımı, cinsiyet, ilaç, yaş vb sebeplerle tükürük akış hızı değişebilir. ${ }^{11}$ Uyarımlı ve uyarımsız tükürük akış hızı değerleri Tablo 1 de gösterilmiştir.

Tablo 1: Tükürük akış hızı değerleri

\begin{tabular}{|l|l|l|l|l|}
\hline & Normal & Düşük & $\begin{array}{l}\text { Çok } \\
\text { düşük }\end{array}$ & Kserostomi \\
\hline Uyarımsız & $>0.25$ & $\begin{array}{l}0.1- \\
0.25\end{array}$ & $<0.1$ & \\
\hline Uyarımlı & $>1.0$ & $\begin{array}{l}0.7- \\
1.0\end{array}$ & $<0.7$ & $<0.1$ \\
\hline
\end{tabular}

\section{Uyarımsız tükürük akış hızı}

- Erişkin hasta dik oturtulur ve başı öne eğdirilir. Bebek veya küçük çocuklarda ağız tabanından pamuk topakçıklar veya pipet yardımıyla tükürük örneği alınır.

- Erişkin hasta steril kaba 5 ile $10 \mathrm{dk}$ arasında tükürür.

- Kapta biriken tükürük ml/dk olarak hesaplanır. ${ }^{12}$

\section{Uyarımlı tükürük akıs hızı}

- Hastaya şekersiz sakız veya parafin birkaç saniye çiğnetilir.

- İlk tükürük hasta tarafından yutulur.

- Sonra 5 dk süresince çiğneme hareketine devam edilir.

- Tükürük biriktikçe steril kaba tükürtülür.

- Biriken tükürük ml/dk olarak hesaplanır. ${ }^{12,13}$

\section{Tükürük ph ölçümü}

Tükürüğün çürük önleyici etkisi; tükürüğün asitbaz dengesine, akışına, tükürüğün tamponlama derecesine ve bakteriler üzerindeki etkisine bağlıdır. ${ }^{14}$ Tükürük içerisinde oluşabilecek farklııklar diş çürüğü riskini iyi veya kötü şekilde etkileyebilir.

Tükürük, antimikrobiyal bileşenlere ve ağız dokularını korumak için harekete geçen tamponlayıcı özellikteki bir maddeye sahiptir. Tükürükteki laktoferrin, lizozim, peroksidaz, defensin ve histatin gibi proteinler, ağız boşluğundaki mikroorganizmaların çoğalmasını engelleyebilir veya bu mikroorganizmaları yok edebilir. ${ }^{15}$

Diş çürüğü, ağızda pH seviyesi 5.5 olduğunda ortaya çıkabilir. Referans için nötr seviye 7.0'dır. Asitli yiyecek ve içecekler tüketildiğinde, ağız içindeki pH düşer ve diş plağındaki pH'nın 5.0'ın altına hızla düşmesine neden olabilir. Bu durum bakterilerin alınan besin maddelerini metabolize ederken asit üretmesiyle meydana gelir. ${ }^{16} \mathrm{Ph}$ değişikliğinde en önemli faktörlerden biri diyettir. Karyojenik ve antikaryojenik gıdalar ağız içi Ph'sını etkiler.

Sonuç olarak tükürüğün önemli bir rolü, kalsiyum ve fosfat iyonu kaynağı sağlayarak diş sert dokularının korunması ile ilgilidir. Diş hidroksiapatitin stabilitesini kontrol eden başlıca faktörler, solüsyonda kalsiyum, fosfat ve florür içermeyen aktif konsantrasyonlar ve tükürük pH'dır. Diş yüzeyindeki değişikliklerin yanı sıra ağızdaki asidik ortamdan dolayı sertlikte azalmalar gözlemlenebilir. Diş yüzeyindeki düşük $\mathrm{pH}$ mineral kaybına yol açar. Diş sağlığı için tükrük pH'ındaki değişiklikler önemlidir. Tükürük $\mathrm{pH}$ ve gıda alımı ile 
ilgili yapılan çalışmaların çoğu bakteri plağı ve çürük gelişimi ile ilişkili olarak yürütülmektedir. ${ }^{17}$

\section{Tampon kapasite testi}

Tampon kapasitesi bir pH metre ya da renk indikatörü kullanımıyla belirlenir. pH metrenin yanı sıra bir titrasyon aletine, laktik asite, baza, parafine ve cam kavanozlara ihtiyaç vardır.

\section{Testin uygulanması;}

- Yemekten sonra toplanmış tükürüğün 10 ml'si en az 1 saat yağ altında bekletilir.

- 5 ml'si, pH metreyi oda sıcaklığına getirdikten sonra, tükürük $\mathrm{pH}$ değeri laktik asit veya baz ilavesiyle 7.0'a ayarlanır.

- Daha sonra, pH 6.0'a ulaşılana kadar laktik asit numuneye eklenir.

- PH'ı 7.0'dan 6.0'a düşürmek için gerekli olan laktik asit miktarı, tampon kapasitesinin bir ölçüsüdür . ${ }^{18}$

Çürük aktivitesi ve tükürüğün tamponlama kapasitesi arasında zıt bir ilişki mevcuttur. Çürük lezyonları fazla olan bireylerin tükürüğünün daha az asittamponlama kapasitesine sahip olduğu bildirilmiştir. Fakat test kesin sonuca ulaşmak için yeterli değildir. ${ }^{19}$

\section{Lactobacillus koloni sayısı tespiti}

Lactobasiller ağızda pH'ın uzunca bir süre düşük olduğu bölgelerde bulunurlar. Diş yüzeyine ilgileri düşük olmakla beraber çürüğün başlangıç bölümlerinde çok etkili olmamasına rağmen ileri evrelerinde etkilidir. ${ }^{20} \mathrm{Bu}$ test, pH'ı 5.0 olan domates pepton agar ile hastadan alınan tükürük örneklerinin inokülasyonunun ardından gözlenen koloni sayısına göre hasta tükürüğündeki asidojenik asidürik bakterilerin sayısını tahmin etmeyi amaçlar. pH'ı 5.0 olan bu ortam Lactobacillus'un çoğalmasını sağlar. Burada kullanılan agar (LBS agar) asidiktir, yüksek asetat ve diğer tuzları içerisinde bulundurabilir, yüzey gerilimi azdır. LBS agarın hassasiyeti net değildir. Çünkü Lactobacillus'un yanında başka organizmalar da çoğalır. Bu uygulamada gözlemlenen kolonilerin toplam sayısı tükürükteki asidürik floranın özelliğini belirtir. Uygulanıcak test için 9 ml'lik iki salin tüpü, tükürük toplama şişeleri, parafin, iki agar yeri, ince cam çubuk, inkübasyon için araçlar ve pipet gerekmektedir. ${ }^{18}$ Koloni sayısının hesaplanması için "quebec counter" bulunmalıdır.

\section{Testin uygulanması;}

- Kahvaltıdan önce parafin çiğneyen hastadan tükürük alınmasıyla başlar daha sonra toplanan tükürük şişeye konur. Karışması için çalkalanır.

- Tükürük örneği, steril salin çözeltisi ile 1:10 seyreltiye ve daha sonra 1: 100 seyreltiye seyreltilir.

- Her seyreltinin $0.4 \mathrm{ml} s i, 20 \mathrm{ml}$ soğutulmuş sıvılaştırılmış agar içeren bir agar plakasının yüzeyine yayılır.

- 3-4 gün $37^{\circ} \mathrm{C}^{\prime}$ de bekletilir.

- Parlak ışık ve geniş bir büyüteçle donatılmış koloni sayacı kullanılarak (quebec counter) koloniler sayılır. ${ }^{18}$

Testin uygulanması kısa sürer, fakat sonuçlar birkaç gün sonra elde edilir. Kolonilerin sayılması çok uzun süren bir işlemdir, bakteriyoloji eğitimi almış personel gerektirir ve pahalı bir uygulamadır. Tablo 2 bize Lactobacillus çürük aktivitesine etkisini göstermektedir.

Tablo 2. Tükürükteki lactobasillusun yorumlanması

\begin{tabular}{|l|l|}
\hline 1 ml tükürükteki Lactobacillus sayısı & Çürük aktivitesi \\
\hline $0-1.000$ & Hafif yada orta \\
\hline $1.000-100.000$ & Biraz \\
\hline $100.000-1.000 .000$ & Orta \\
\hline$>1.000 .000$ & Belirgin \\
\hline
\end{tabular}

\section{Kolorimetrik snyder testi}

Bir karbonhidrat ortamından organik asit oluşturmak için tükürük mikroorganizmalarının yeteneğini ölçer. Tükürükte bulunan hem asidürik hem de asidojenik organizmaların sayısını dolaylı olarak ölçer. Örneklenen stimüle tükürüğün glikoz içeren 4.7-5 pH'lık agar ortamında asit üretiminin oranını ölçer. Ortamda "Bromocresol yeşili" gösterge boyası bulunur, pH 5,4'ten 3,8'e değiştiğinde yeşilden sarıya değişir.

\section{Testin uygulanması;}

- Sabah herhangi bir yemek yemeden önce çiğnenen parafinle toplanmış 0.2 ml'lik tükürük eritilmiş agar içeren test tüpü içinde pipet yardımı ile karıştırııır.

- Katılaşması için $37^{\circ} \mathrm{C}$ de bekletilir.

- Asidojenik organizmalarca üretilen asit miktarı pH indikatöründeki değişikliklere göre hesaplanır.

- 24, 48 ve 72 saat sonrasında bir kontrol tüpüyle karşılaştırılır. ${ }^{18}$

Bu test basittir. 24-48 saatte uygulanır ve basit araçlar gerektirir. Test sonuçlarının negatif olmasıyla çürük aktivitenin yokluğu arasında anlam kurulmuştur. Özel muayenehaneler için Snyder Testinin daha basite indirgenmiş çeşitleri önerilmektedir. Bunlardan birinde 
pipet kullanımı yerine tel lup kullanılarak karıştırma işlemi gerçekleştirilir. Bu pipetlerde oluşabilecek hava boşluğunu engeller. Bir diğeri ise dişin bukkal yüzeyleri pamuk peletle silinerek bunların Snyder ortamında bekletilmesini içerir. Bu plaktan direkt olarak kültür alınması için bir üstünlük sağlar. ${ }^{20,21}$ Şekil 2 ve Tablo 3 bize synder testinin aşamalarını göstermektedir.

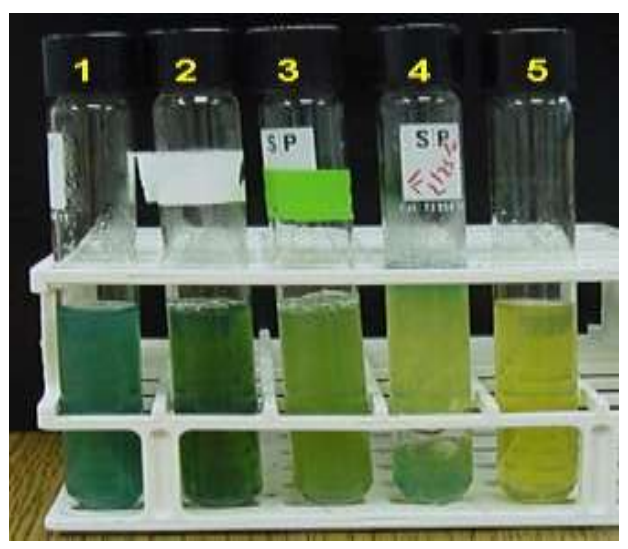

Şekil 1. Synder testi uygulanmış tükürük

Tablo 3. Synder testinin yorumlanması

\begin{tabular}{|c|c|c|c|}
\hline & \multicolumn{3}{|c|}{ Zamen (santlet) } \\
\hline & 24 & 48 & 72 \\
\hline Renk & San & Sen & 5 an \\
\hline Çuruk aktinitest & Belingin & Kesin & Az saynda \\
\hline Renk & Yeagl & Yeil & Yeati \\
\hline Çlank alativitesi & Test verduruler & Test sürduruler & Inaktif \\
\hline
\end{tabular}

\section{Redüktaz testi}

Bir boya olan diazorezorsinol kullanılarak tükürük bakterilerinde bulunan redüktaz enziminin aktivitesini incelenmektedir. Redüktaz testi, içinde tükürük toplama tüpleri, tüpün kapağında aktivatör ve tatlandırımış parafin bulundurmaktadır.

\section{Testin uygulanması;}

- Parafinin çiğnenmesi sonrası kişinin tükürüğü toplanır.

- Toplanan tükürük diazorezorsinol ile karıştırıır.

- Çürük aktivitesi $15 \mathrm{dk}$ sonra gözlemlenen renge göre ölçülür. ${ }^{18}$

Klinik çürük varlı̆ıyla bu testin sonuçlarının iyi bir korelasyon göstermediği bildirilmiştir. ${ }^{21}$ Tablo 4 redüktaz testinin çürük aktivitesinde nasıl yorumlandığını göstermektedir.
Tablo 4. Redüktaz testinin yorumlanması

\begin{tabular}{|l|c|c|l|}
\hline Renk & Zaman & Skor & Cürük aktivitesi \\
\hline Mavi & $15 \mathrm{dk}$ & 1 & Etken yok \\
\hline Turuncu & $15 \mathrm{dk}$ & 2 & Etken az \\
\hline Kırmıı & $15 \mathrm{dk}$ & 3 & Etken belirgin \\
\hline Kırmızı & Hemen & 4 & Etken Yüksek \\
\hline Pembe yada Beyaz & Hemen & 5 & Etken Çok Fazla \\
\hline
\end{tabular}

\section{Fordisk kalsiyum eritme testi}

Toz hali oluşturulmuş mine ve glikozla hastanın tükürüğü karıştırıdığında asit formuyla 4 saatte eriyen minenin miligramını ölçmektedir. Toz insan diş minesine, steril test tüplerine, tükürüğün kalsiyum içeriğini belirlemek için kullanılan bir araca, tükürük toplama şişeleri ve test tüpünü çalkalama aracına intiyaç vardır. Ayrıca sakız ya da parafin gerekmek- tedir. Sakızla uyarılan tükürüğün 2,5 ml'si alınır, bunun bir bölümü kalsiyum içeriğini saptamak için incelenir ve analiz edilir. Diğer bölümü ise $0.1 \mathrm{gr} 8$ inçlik steril bir tüpe alınır. Test tüpü kapatııır ve 4 saat kadar çalkalanır. İşlem tamamlandıktan sonra test tüpü içindeki tükürüğün kalsiyum içeriği yeniden analiz edilir. Kalsiyum miktarı arttıkça çürük riski artar. ${ }^{18}$ Tükürüğün stimülasyonu için sakız çiğnenmesi şekeri ortaya çıkarır. Parafin kullanilırsa \%5 kadar glikoz konsantrasyonu eklenmektedir. Minenin erime miktarı arttığında çürük aktivitesinin arttığı bildirilmektedir. Fakat uygulanması zor bir testtir, spesifik aletler ve eğitimli personel gerektirmektedir. Ayrıca maliyeti de yüksektir. ${ }^{4}$

\section{Streptokok grubu mutansları tarama testleri}

Yapılan araştırmalarda diş çürüğü ile ağız içindeki $S$. mutans düzeyi arasında pozitif bir ilişki bildirilmiştir. ${ }^{22,23}$ S.mutans'n; kolonize olduğu diş yüzeyinde diğer bakteriler ve konağa karşı immünite sağlayabildiğini gösteren güncel çalışmalar bulunmaktadır. ${ }^{24}$

S. mutans türleri intiyaç duydukları aminoasitleri kendileri üretebilirler. Diş çürüklerinde en etkili olan organizma olmasının ve her tür çürük lezyonunda sıkça görülmesinin sebebinin bu olduğu düşünülmektedir. ${ }^{25}$

İnsan oral kavitesinden alınan $S$. mutans çocuklarda ve yetişkinlerde kuronal çürükte, yetişkinlerde kök yüzey çürüklerinde ve genç erişkinlerde rampant çürükte ve biberon çürüğünde saptanmıştır. ${ }^{26}$ Streptokok grubu mutanslarda 7 tür tespit edilmiş fakat $S$. mutans ve $S$. sobrinus'un insan tükürük ve diş 
plağında daha dominant olduğu kabul edilmektedir. ${ }^{27}$ S.sobrinus kolonileri sık olarak S.mutans olarak tanımlanmaktadır. İki bakteri arasındaki ayrımı yapabilmek için monoklonal antikorlar üretilmiştir. S.mutans'ın asit üretimi dururken; $\mathrm{PH}$ 5.5'in altında S.sobrinusun asit üretimi sürer. S.mutans oklüzal fissürlerde, S.sobrinus ise dişin düz alanlarında bulunmaktadır. ${ }^{19}$ Dişsiz çocuklarda $S$. Mutans'a rastlanmamaktadır. $S$. mutans ilk 6 ay ila 1 yaş arası keser dişleri süren bebeklerde belirlenmiştir. Yapılan araştırmalarda S.mutans'ın diş yüzeyine ihtiyaç duyduğu belirtirmiştir. $\mathrm{Bu}$ nedenledir ki süt dişlerinin sayısının artmasıyla beraber S.mutans sayısında da artış gözlemlenir. ${ }^{28,29}$ Yapılan çalışmalarda tedavi edilen çocuk hastalarda S.mutans sayısında azalma görülmüş fakat hiçbirinde bu sayı 0 seviyesinde olmamıştır. ${ }^{22}$

\section{Testin uygulanması;}

- Ağız içinden tahta spatula yardımıyla örnek toplanır.

- $\quad$ MSB agara spatulalar bastırılır.

- $\quad 37^{\circ} \mathrm{C}^{\prime}$ de 48 saat \%5'lik CO2 gazı karışımında inkübasyon yapilır.

- $\mathrm{Kob} / \mathrm{ml}$ olarak hesaplanır (tablo 5).

Tablo 5. Tükürük mutans streptokok düzeyleri

\begin{tabular}{|l|l|}
\hline \multicolumn{2}{|c|}{ Tükürük mutans streptokok düzeyleri } \\
\hline Yüksek düzey & $\geq 10^{6} \mathrm{kob} / \mathrm{ml}$ \\
\hline Orta düzey & $\geq 10^{5}<10^{6} \mathrm{kob} / \mathrm{ml}$ \\
\hline Düşük düzey & $<\mathbf{1 0 ^ { 5 }} \mathrm{kob} / \mathrm{ml}$ \\
\hline
\end{tabular}

Tablo 6. Çürük aktivite testlerinin karşılaştıııması

\begin{tabular}{|c|c|c|c|}
\hline mot & $t=1$ & what & Ded tammen \\
\hline 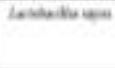 & 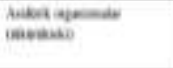 & $\begin{array}{l}\text { Maviogen } \\
\text { sav stion }\end{array}$ & 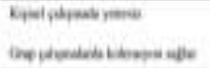 \\
\hline Intit & 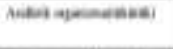 & $\lim _{\operatorname{mon}}$ & 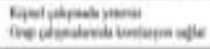 \\
\hline thete & 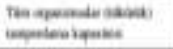 & 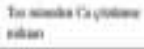 & henes \\
\hline b.bas & 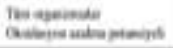 & imiat & 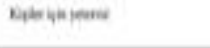 \\
\hline Terpitaper & Tepenianere & fonesedian & 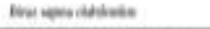 \\
\hline tresine & ingenteis & indensed & 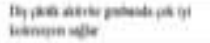 \\
\hline
\end{tabular}

\section{Diş çürüğü risk belirleme yöntemleri}

\section{Karyogram;}

Çürük risk değerlendirilmesi diş hekiminin hastanın karyojenik profilini daha iyi anlamasına yardımcı olan önemli bir araçtır. Çürük risk profili hızlı bir şekilde ve kolaylıkla elde edilmelidir. Bu durumlar göz önüne alındığında çürük sonuçlarını tahmin etme kabiliyeti hakkında farklı metotlar incelenmiştir. Çürük riskinin karmaşık olması, hepsi doğrulanmamış farklı protokollerin geliştirilmesine yol açmıştır. Karyogram, İsveç'te geliştirilmiş bir software programıdır, çürük riskini değerlendirmede klinik olarak etkisi kanıtlanmış olduğundan dikkat çekmektedir. ${ }^{30,31}$

Bilgisayar bazlı bir program olan karyogram üzerinde kapsamlı bir şekilde çalışılmıştır; Karyogram, hastanın geçmişi ve klinik datasının girilmesi sonucu bir risk profili oluşturur. Mesleki incelemeye ve verilen karara ek olarak hastanın çürük deneyimini, sistemik hastalıklarını, diyet içeriklerine, plak miktarına, tükürükteki Streptococcus mutans sayısını, florür kaynaklarını, tükürük salgılama ve tampon kapasitesini inceleyen bir programdır. Aynı zamanda internetten indirile bilmesi herkes tarafından kullanılmasına olanak sağlar. ${ }^{32}$

\section{Karyogramda skorlama;}

Programın sağ tarafında çürüğe ait verilen faktörlerin skorlaması yapılır. Bu bölgedeki her faktör 0 ile 2 arasında ya da 0 ile 3 arasında skorlanır. 0 düşük riski gösteren olumlu yönde bir skorken 2 ve ya 3 yüksek riski gösterir.

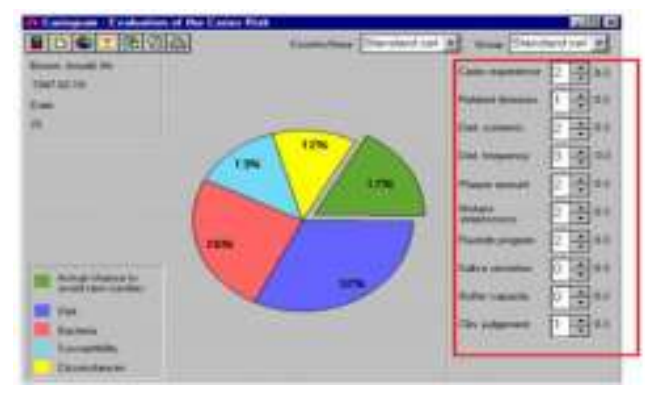

Şekil 2. Karyogram örneği

Karyogramın 5 bölümü vardır (Şekil 2). Yeşil kısım yeni diş çürüğü oluşumundan kaçınma yüzdesini gösterir. Diğer faktörler segmentleri doldurduğunda geriye kalan kısmı gösterir. Koyu mavi kısım diyet içeriği ve diyet sıklığını, kırmızı kısım bakteriyi ve turkuaz kısım duyarlılığı gösterir. Sarı kısım ise geçmiş çürük deneyimini ve ilgili hastalıkları gösterir. ${ }^{33}$

Karyogramın amaçları ve işlevleri;

- Farklı faktörlerin hangi ölçüde etkilediğini görebilmek

- Yeni kaviteler gelişmeden önleyici tedbirlerin alınmasına teşvik etmek.

- Klinikte kullanılabilir. 
IMREN, KORUYUCU,

TUNA İNCE, AKINCI

- Eğitim programı olarak kullanılabilir.

- Çürüklerle ilgili faktörlerin etkileşimini gösterir.

- Çürüğü önleme şansını gösterir.

- Çürük riskini grafiksel olarak ifade eder.

- Hedeflenen önleyici faaliyetleri önerir. ${ }^{33}$

\section{Karyogramın önemi;}

Çürük aktivite testleri tek başına kullanıldıkları zaman yeterince güvenilir değildir. Testlerin kombine edilmesiyle birlikte risk gruplarının belirlenmesinde daha sağlıkı sonuçlar oluşturulmaktadır. Karyogram programındaki skorlamalar, çürük aktivite testlerinin uygulanmasıyla belirlenir. Böylece testler birlikte kullanılarak elde edilen sonucun güvenilirliği artar.

\section{SONUÇ}

Diş çürüğü dünyada en sık gözüken kronik hastalıktır. Diş çürüğü oluşumunda beslenme, sosyoekonomik faktörler, ilaç kullanımı gibi dış etkenler olmasıyla birlikte tükürük, kronik hastalıklar, dişe ait faktörler gibi içsel nedenler de bulunmaktadır. Bireylerde bu etkili faktörlerin önceden belirlenip değiştirilmesi, koruyucu uygulamaların yapılması büyük önem taşır. Bu amaçla çürük riskini belirlemek için yöntemler geliştirilmiştir.

Çürük riskinin belirlenmesi; bireyler, gruplar ve toplumlar üzerinde kullanılan bir yöntemdir. Kullanım amaçlarından en önemlisi doğru ve etkin tedavi planına hızı bir şekilde ulaşmaktır. Aynı zamanda toplumda çürük riski yüksek bireylerin saptanması ile koruyucu önlemlerin hangi yoğunlukta uygulanacağı programlanır.

Çürük aktivitesinin incelenmesi için birçok test geliştirilmiştir. Lactobasillus koloni sayısı tespiti, synder testi, redüktaz testi, tükürüğün her açıdan incelenmesi ile bireylerin yüksek, orta veya düşük risk grubunda olup olmadığı belirlenmeye çalışılır. Diş çürüğü oluşumunda birçok faktör etkilidir. Bu nedenle testler tek başına kullanıldıkları zaman yeterince güve- nilir değildir. Testlerin kombine edilmesiyle birlikte risk gruplarının belirlenmesinde daha sağlıklı sonuçlar oluşturulmaktadır. Teknolojinin gelişimiyle birlikte çürük oluşumunda etkili çok sayıdaki farklı etkenlerin kolay ve kısa sürede analiz edilebileceği belirtilmektedir.

NOT: Calışmada herhangi bir yazar, kurum ya da kurulus ile çıkar çatışması içerisinde bulunmamaktadır. Makale daha önce hiçbir yerde yayınlanmamıs ve yayınlanmak üzere işlem görmemektedir

\section{KAYNAKLAR}

1. Mandel ID. The role of saliva in maintaining oral homeostasis. J Am Dent Assoc 1989;119:298-304.

2. Moran J, Addy M, Newcombe R. A clinical trial to assess the efficacy of sanguinarine-zinc mouthrinse (Veadent) compared with chlorhexidine mouthrinse (Corsodyl). J Clin Periodontol 1988; 15:612-6.

3. World Health Organization. Review of methods of identification of high caries risk groups and individual. Federation Dentaire Internationale. Technical Report No. 31. Int Dent J 1988; 38:1-3.

4. Taşveren SK, Akal N. Çürük Aktivite Testleri. Ondokuz Mayıs Üniv Diş Hek Fak Derg 2015;7: 4554.

5. Özgür B, Ünverdi GE, Çehreli Z. Diş Çürüğünün Tespitinde Geleneksel ve Güncel Yaklaşımlar. Turkiye Klinikleri J Pediatric Dentistry-Special Topics 2018; 4: 1-9.

6. Gul P, Akgul N, Catakci AG, Atila A. Effects of of xylitol chewing gum, black tea and white cheese on saliva ph. J Dent Fac Atatürk Univ 2011; 21: 88-93.

7. Olszowski T, Adler G, Janiszewska-Olszowska J, Safranow K, Kaczmarczyk M. MBL2, MASP2, AMELX, and ENAM gene polymorphisms and dental caries in Polish children. Oral Diseases 2012;18: 389-95.

8. Featherstone JD, Domejean-Orliaguet $S$, Jenson $L$, Wolff $M$, Young DA. Caries risk assessment in practice for age 6 through adult. CDA 2007; 35: 710-3.

9. Edgar WM. Saliva: its secretion, composition and functions. Br Dent J 1992;172: 305-12.

10. Sreebny LM. Saliva: Its role in health and disease. Working group 10 of the commission on oral health, research and epidemiology (CORE). Int Dent J 1992; 42:287-304.

11. Larmas M. Simple tests for caries susceptibility. Int Dent J 1985; 35: 109-17.

12. Kavanagh DA, Svehla G. Variation of salivary calcium, phosphate and buffering capacity in adolescents. Arch Oral Biol 1998; 43:1023-7.

13. Socransky SS, Manganiello SD. The oral microbiota of man from birth to senility. J Periodontol 1971; 42:485-96

14. Ben-Aryeh H, Fisher M, Szargel R, Laufer D. Composition of whole unstimulated saliva of healthy children: changes with age. Arch Oral Biol 1990; 35:929-31. 
15. Pandey P, Reddy NV, Rao VAP, Saxena A, Chaudhary CP. Estimation of salivary flow rate, $\mathrm{pH}$, buffer capacity, calcium, total protein content and total antioxidant capacity in relation to dental caries severity, age and gender. Contemporary Clin Dent 2015; 6:65.

16. Marsh PD. Microbial ecology of dental plaque and its significance in health and disease. Adv Dent Res 1994; 8:263-71.

17. De Almeida PDV, Gregio AM., Machado MA, De Lima AA, Azevedo LR. Saliva composition and functions: a comprehensive review. J Contemp Dent Pract 2008;9: 72-80.

18. Nikhila N, Arun A, Mythri H. Caries Activity Tests. Journal of Dental Sciences 2013; 1: 50-59.

19. De Soet JJ, Van Dalen PJ, Appelmelk BJ, De Graaff J. Identification of Streptococcus sobrinus with monoclonal antibodies. J Clin Microbiol 1987; 25:2285-8.

20. Van Houte J. Microbiological predictors of caries risk. Advances in Dental Research 1993;7: 87-96.

21. Emilson CG, Krasse BO. Support for and implications of the specific plaque hypothesis. Eur J Oral Sci 1985; 93:96-104.

22. Duru DÖ, Kırzıoğlu Z, Ayyıldız A. 3-6 yaş grubu çocuklarda çürük aktivite testleri ve çürük prevalansı arasındaki ilişki. Atatürk Üniv Diş Hek Fak Derg 1999; 3-6.

23. Russell JI, MacFarlane TW, Aitchison TC, Stephen $\mathrm{KW}$, Burchell CK. Caries prevalence and microbiological and salivary caries activity tests in Scottish adolescents. Commun Dent Oral Epidemiol 1990; 18:120-5.

24. Lemos JA, Burne RA. A model of efficiency: stress tolerance by Streptococcus mutans. Microbiology 2008; 154:3247-55.

25. Kuramitsu HK, Wang BY. The whole is greater than the sum of its parts: dental plaque bacterial interactions can affect the virulence properties of cariogenic Streptococcus mutans. Am J Dent 2011; 24:153-4.

26. Camling E, Emilson CG. Results with the caries activity test" Cariostat" compared to prevalence of mutans streptococci and lactobacilli. Swed Dent J 1989;13:125-30.

27. Schaeken MJM, Van der Hoeven JS, Franken HCM. Comparative recovery of Streptococcus mutans on five isolation media, including a new simple selective medium. J Dent Res 1986; 65:906-8.
28. Fujiwara T, Sasada E, Mima N, Ooshima T. Caries prevalence and salivary mutans streptococci in 02-year-old children of Japan. Community Dent Oral Epidemiol 1991; 19:151-4.

29. Suhonen J, Sener B, Bucher W, Lutz F. Release of preventive agents from pacifiers in vitro. An Introduc Nov Prevent Measur 1994; 104:946-51.

30. Alian AY, Mcnally M, Fure S, Birkhed D. Assessment of caries risk in elderly patients using the Cariogram model. J Canad Dent Assoc 2006; 72:459-63.

31. Bratthall D, Hänsel Petersson G Cariogram-a multifactorial risk assessment model for a multifactorial disease. Community Dent Oral Epidemiol 2005; 33:256-64.

32. Çelik EU, Gökay N, Ateş M. Efficiency of caries risk assessment in young adults using Cariogram. Eur J Dent 2012; 6: 270.

33. Bratthall D, Hänsel Petersson G, Stjernsward JR. Cariogam manual. Internet Version 2.01, 2004.

\author{
Yazışma Adresi \\ Dok. Öğr. Dt. Ayberk İmren \\ İstanbul Üniversitesi Diş Hekimliği Fakültesi \\ Pedodonti Anabilim Dalı \\ Fatih/İstanbul \\ Tel: 0(539) 5886995 \\ e-mail: ayberkimren1995@gmail.com
}

